\title{
Lupine embryo axes under salinity stress. I. Ultrastructural response
}

\author{
Łukasz Wojtyla $\cdot$ Renata Rucińska-Sobkowiak • \\ Szymon Kubala $\cdot$ Małgorzata Garnczarska
}

Received: 9 November 2012/Revised: 10 January 2013/Accepted: 4 March 2013/Published online: 22 March 2013

(C) The Author(s) 2013. This article is published with open access at Springerlink.com

\begin{abstract}
Embryonic root is the primary site of salinity perception in germinating seeds. To understand better the $\mathrm{NaCl}$ stress response of lupine embryo axes, ultrastructural approach combined with analysis of DNA degradation was used. In this study lupine embryo axes were cultured in vitro on the medium supplemented with two salt concentrations 250 and $500 \mathrm{mM}$ to differ the reaction. To assess the rate of DNA damage, alkaline electrophoresis of isolated nuclei and DNA fragmentation analysis were performed. Results of these studies suggest programmed cell death induction under salinity stress. Moreover, ultrastructure observations revealed other characteristic features of programmed cell death like endoplasmic reticulum reorganization, increased level of vacuolization, chromatin condensation and starch grains degradation. Our comparative analysis of ultrastructure changes and DNA fragmentation speak in favour of programmed cell death in lupine (Lupinus luteus L. 'Mister') embryo axes treated for $12 \mathrm{~h}$ with 250 and $500 \mathrm{mM} \mathrm{NaCl}$.
\end{abstract}

Keywords Salinity stress - Ultrastructure · Plant programmed cell death

Communicated by S. Weidner.

Ł. Wojtyla · S. Kubala · M. Garnczarska $(\bowtie)$

Department of Plant Physiology, Faculty of Biology,

Adam Mickiewicz University, ul. Umultowska 89,

61-614 Poznan, Poland

e-mail: garnczar@amu.edu.pl

R. Rucińska-Sobkowiak

Department of Plant Ecophysiology, Faculty of Biology,

Adam Mickiewicz University, ul. Umultowska 89,

61-614 Poznan, Poland

\section{Introduction}

Salinity stress is one of the major abiotic stresses affecting plants growth and breeding. Under saline conditions a reduction of plant growth as well as yield reduction or even lack of generative phase in the ontogenesis is observed. Salinity leads to a number of changes in the functioning of plant cells through the cytotoxic effect of $\mathrm{Na}^{+}$and $\mathrm{Cl}^{-}$on the cells, the disturbance of mineral nutrition and decrease in soil water potential, which causes osmotic stress. Influx of $\mathrm{Na}^{+}$into cell causes the efflux of $\mathrm{K}^{+}$out of the cells and elevation in cytosolic $\mathrm{Ca}^{2+}$ pool (Zhu 2002). Salinity stress disorders homeostasis of $\mathrm{Na}^{+}, \mathrm{K}^{+}$and $\mathrm{Ca}^{2+}$ ion pools which cause elevation of reactive oxygen species (ROS) level and activation of antioxidant systems (Miller et al. 2010). The increase in ROS levels and ionic disturbance lead to an increase in mitochondrial membrane permeability and efflux of cytochrome $c$ into the cytosol that results in programmed cell death (PCD) (de Pinto et al. 2012). The mechanism for ions signalling leading to PCD execution in plant cells under salinity has been proposed by Shabala (2009). $\mathrm{Na}^{+}$ions uptake under saline condition cause strong membrane depolarization promoted by $\mathrm{K}^{+}$ efflux via depolarization-activated outward-rectifying $\mathrm{K}^{+}$ channels (Shabala et al. 2006). A decrease in the cytosolic $\mathrm{K}^{+}$pool activates caspase-like proteases leading to PCD after $\mathrm{NaCl}$ treatment (Shabala 2009).

Plant PCD was observed under the influence of abiotic stress factors such as heat shock (Qu et al. 2009), cold stress (Koukalová et al. 1997), micronutrient deficiency (Koshiba et al. 2008), or heavy metals, mainly cadmium $\mathrm{Cd}^{2+}$ treatment (Ma et al. 2010). Stress caused by salinity may also lead to PCD induction. Symptoms of PCD under the influence of salinity were observed and reported in unicellular algae Micrasterias denticulata (Affenzeller 
et al. 2009), tobacco protoplasts (Lin et al. 2006), the cell suspension of Thellungiella halophila (Wang et al. 2010), the roots of Arabidopsis thaliana (Huh et al. 2002), the root tips of rice Oryza sativa (Chen et al. 2009) and in the cells of mesophilic tobacco leaf Nicotiana tabacum (Andronis and Roubelakis-Angelakis 2010).

In this study experiments were conducted on embryonic axes isolated from lupine seeds and grown in vitro on medium supplemented with $\mathrm{NaCl}$ to establish a salinityinduced PCD model. Seed germination and seedling growth have been reported to be relatively more sensitive towards salinity (Ashraf and McNeilly 2004). The embryonic radicle is the first part of plant that has a direct contact with the soil. Embryonic root is the organ that has direct contact with the ground, and therefore also with the salt in a situation of excessive salinity. The influx of ions also takes place in roots.

The aim of the study was to provide new insights into lupine embryonic axes response to salinity at ultrastructural level. Ultrastructural changes were discussed in relation to morphological features as a way of classification of plant cell death (Doorn et al. 2011). By integrating the ultrastructural changes that occur under salinity stress with observation of nuclear DNA fragmentation, we showed that strong salinity stress leads to PCD execution in lupine embryo axes.

\section{Materials and methods}

In vitro culture of embryonic axes

Seeds of yellow lupine (Lupinus luteus L. 'Mister') were obtained from Poznań Plant Breeders Ltd. Seeds were surface-sterilized in $0.02 \%$ mercuric chloride for $5 \mathrm{~min}$ and in $0.5 \%$ sodium hypochlorite for $10 \mathrm{~min}$, rinsed and allowed to imbibe for $24 \mathrm{~h}$ at $25^{\circ} \mathrm{C}$. Embryonic axes isolated from imbibed seeds were grown in vitro for $12 \mathrm{~h}$ on Heller (1953) medium supplemented with $60 \mathrm{mM}$ sucrose (Borek et al. 2006) and with addition of 250 or $500 \mathrm{mM}$ sodium chloride or without $\mathrm{NaCl}$ (control). In vitro culture was carried out in dark at $25^{\circ} \mathrm{C}$ on a gyratory shaker (150 rpm).

DNA laddering observation

$1 \mathrm{~g}$ of crushed plant tissue was mixed with $500 \mu \mathrm{l}$ of DNA extraction buffer (Edwards et al. 1991) and treated with RNase (Fermentas) for $30 \mathrm{~min}$ at $32{ }^{\circ} \mathrm{C}$ on vortex to remove RNA from the samples. DNA isolation was done by phenol/chloroform extraction (Edwards et al. 1991). Precipitation of DNA was done by addition of 0.6 volume of isopropanol. DNA was pelleted by centrifugation and dried for $1 \mathrm{~h}$. DNA pellet was dissolved in $100 \mu \mathrm{l}$ of water at $4{ }^{\circ} \mathrm{C}$ overnight. The quantity of DNA was measured using NanoDrop (Thermo Scientific). DNA electrophoresis was carried on $2 \%$ agarose in $0.5 \times$ TBE buffer $(44.5 \mathrm{mM}$ Tris, $44.5 \mathrm{mM}$ boric acid, $1 \mathrm{mM}$ EDTA $\mathrm{pH} 8.0$ ) with ethidium bromide and visualized under UV light.

Alkaline electrophoresis of isolated nuclei

The nuclei of the embryo axis cells were isolated as described by Pfosser et al. (1995). The degree of DNA damage was determined using the alkaline comet assay, as described by Rucińska et al. (2004). Electrophoresis was conducted for $25 \mathrm{~min}$ at $25 \mathrm{~V}\left(1 \mathrm{~V} \mathrm{~cm}^{-1}\right)$ in a chamber cooled on ice. DNA was stained with $1 \mu \mathrm{M}$ DAPI (4'-6diamidino-2-phenylindole) for $24 \mathrm{~h}$. The comets were observed using a fluorescent microscope. The extent of DNA migration was determined using the ScionImage image analysis system and macro Comet_Scoring_Macro for optimize the measurements. Three parameters of the comets analyzed were: tail area (TA), tail length (TL) and Olive tail moment (OTM). To determine statistical difference with nonparametric distribution the Kruskal-Wallis analysis of variance test was used.

\section{Oxygen consumption}

Oxygen consumption of lupine embryo axis was measured in a Clark-type oxygen electrode (Rank Brothers) in $5 \mathrm{~mL}$ of medium containing $0.05 \mathrm{M} \mathrm{K}_{2} \mathrm{HPO}_{4} / \mathrm{KH}_{2} \mathrm{PO}_{4}$ buffer $\mathrm{pH}$ 7.5. Respiration rates were measured in dark at $25^{\circ} \mathrm{C}$. For each analysis three to five embryo axes were used. The results are mean $\pm \mathrm{SD}$ of five independent experiments.

Loss in cell integrity measurement

To measure the degree of cell membrane disintegration under salinity stress tissue staining with Evans blue solution was used. Lupine embryo axes were stained with $0.5 \%$ (w/v) Evans blue water solution for 5 min (Baker and Mock 1994). After this time axes were rinsed five times with distilled water to remove excess unbound dye. Determination of the degree of embryo axes injury was done as described by Rucińska et al. (2004).

Transmission electron microscope

Preparation of embryo axes for transmission electron microscopy (TEM) was carried according to Borek et al. (2006). Embryo axes were fixed in Karnowsky halfstrength fixative (Karnowsky 1965), i.e. in a mixture of $2 \%$ glutaraldehyde and $2 \%$ paraformaldehyde. Postfixation was conducted in $1 \% \mathrm{OsO}_{4}$ for $2 \mathrm{~h}$. The samples 

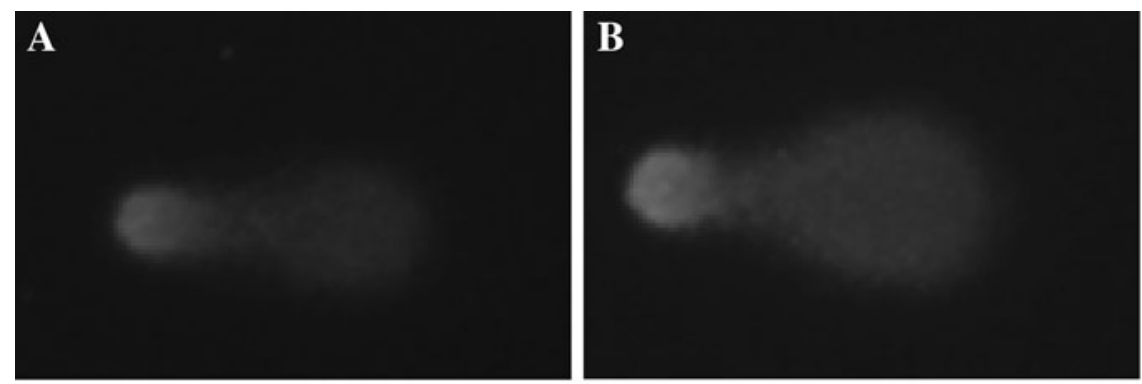

D

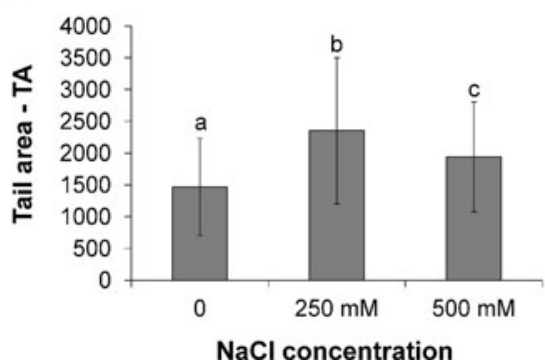

E

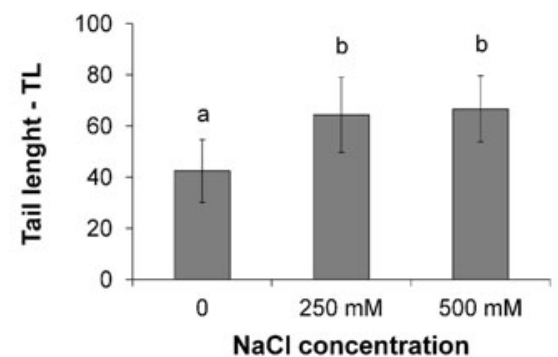

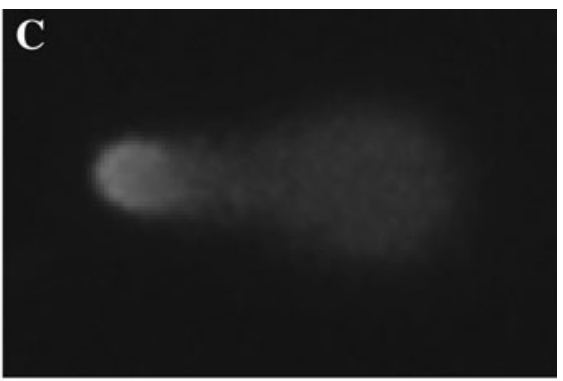

F

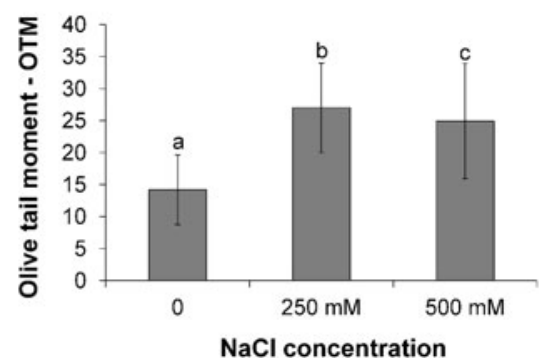

Fig. 1 DAPI visualization of released DNA in agarose after alkaline electrophoresis of lupine embryo axes nuclei. Embryo axes were grown in control medium (a) with $250 \mathrm{mM}$ (b) and $500 \mathrm{mM} \mathrm{NaCl}$ (c). Three parameters of comets of DNA observed after alkaline electrophoresis of nuclei isolated from lupine embryo axes were analyzed: $T A$ tail area (d), $T L$ tail length (e) and $O T M$ olive tail moment (f). The measurements were taken for around 150 comets for control, 250 and $500 \mathrm{mM} \mathrm{NaCl}$ treatment. Means denoted by the same letter were not significantly different at $\alpha=0.01$ according to Kruskal-Wallis analysis of variance test with nonparametric distribution were stained in $2 \%$ aqueous solution of uranyl acetate. Dehydration was performed in a series of acetone solutions. The objects were embedded in epoxy resin of low viscosity (Spurr 1969). Ultrathin cross-sections were obtained with Ultracut S (Raichert) and poststained on grids in $5 \%$ uranyl acetate and $0.5 \%$ lead citrate and observed under the transmission electron microscope TEM-1200 Ex JEOL.

\section{Results}

DNA degradation under salinity

To analyze DNA damage in lupine embryo axes in response to salinity, alkaline comet assay of isolated nuclei was applied. Electrophoresis conditions were matched to give the result of characteristic comet images for each experimental variant, including control axes (Fig. 1). This experimental protocol allowed to compare the salinity treated axes to the control. Three parameters of comets were analyzed: tail area (TA), tail length (TL) and Olive tail moment (OTM) (Fig. 1a, b, c). All parameters had higher values in embryonic axes exposed to $\mathrm{NaCl}$ than in control. However, TA (Fig. 1d) and OTM (Fig. 1f) had the highest values in embryonic axes treated with $250 \mathrm{mM} \mathrm{NaCl}$ for $12 \mathrm{~h}$, whereas TL (Fig. 1e) had the highest value in $500 \mathrm{mM}$ treatment. To confirm the obtained results of DNA degradation, DNA laddering analysis was employed. DNA was isolated from plant material and separated by electrophoresis in $2 \%$ agarose gel. Nuclear DNAs from lupine embryo axes exposed to 250 and $500 \mathrm{mM} \mathrm{NaCl}$ for $12 \mathrm{~h}$ were fragmentized into internucleosomal fragments of around $180 \mathrm{Bp}$ and their multiple (Fig. 2).

Determination of the degree of embryo axis injury

To assess cells-membrane integrity Evans blue dye was applied. Loss of plasma membrane integrity within cells in lupine embryo axes increased dose-dependently. The uptake of Evans blue solution by cells was 1.1 and 1.4-fold higher in 250 and $500 \mathrm{mM} \mathrm{NaCl}$ treatment, respectively, as compared to the control (Fig. 3).

\section{Oxygen consumption}

Oxygen consumption was measured for whole embryo axes in phosphate buffer $\mathrm{pH}$ 7.5. The rate of oxygen consumption was in $\mathrm{nM} \mathrm{O} / \mathrm{min} / \mathrm{g}$ of fresh weight. Oxygen consumption decreased in relation to $\mathrm{NaCl}$ content in growing medium (Table 1). 


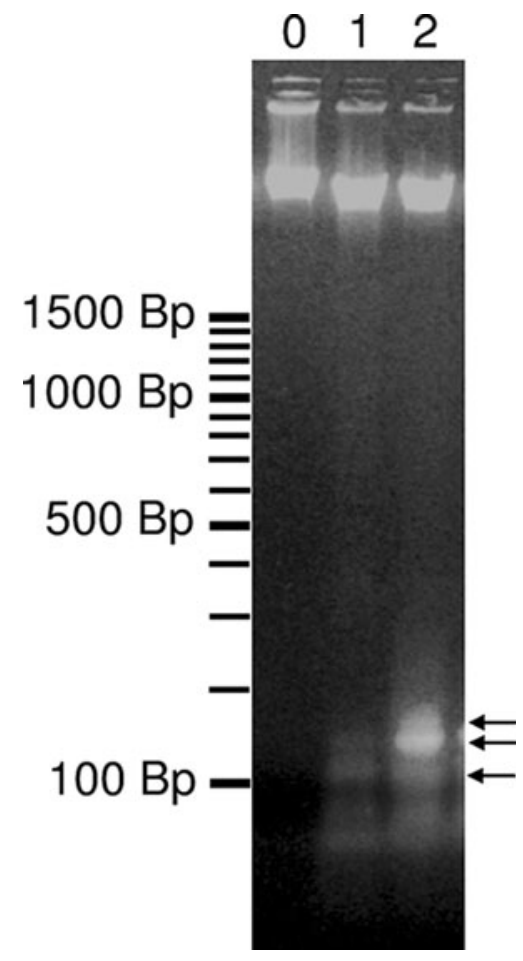

Fig. 2 Separation of genomic DNA in $2 \%$ agarose gel and staining with ethidium bromide showing specific DNA degradation in the ladder-like form under $250 \mathrm{mM}(1)$, and $500 \mathrm{mM} \mathrm{(2)} \mathrm{NaCl}$ treatment compared to control $(0) .10,000$ ng of DNA was loaded to each well

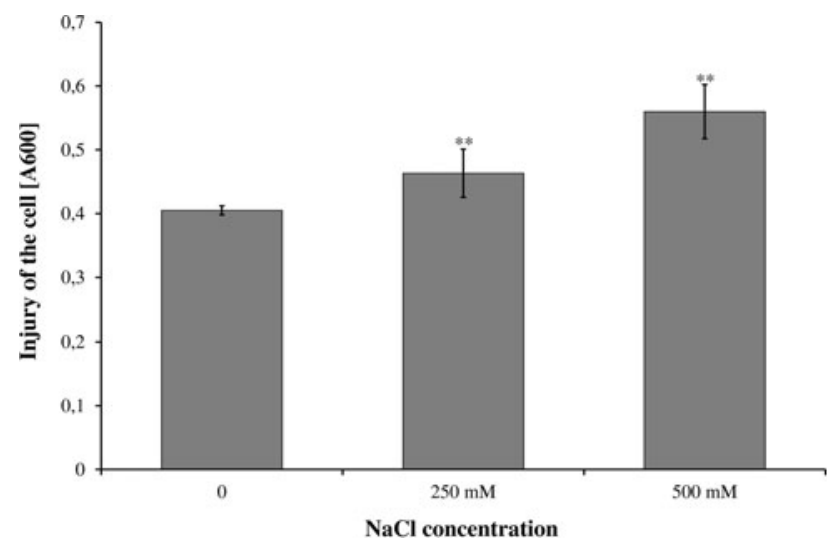

Fig. 3 Salinity effect on embryo axes injury. The degree of embryo axes injury was measured after $12 \mathrm{~h}$ incubation in control condition or exposure to 250 and $500 \mathrm{mM} \mathrm{NaCl}$. The injury was determined by Evans blue staining and quantified by measuring absorbance at $600 \mathrm{~nm}$. Values are the mean $\pm \mathrm{SD}$ of three independent experiments

\section{Ultrastructure observation}

Ultrastructure analyses of cells of the radicle meristematic zone of lupine embryonic axes treated for $12 \mathrm{~h}$ with 250 and $500 \mathrm{mM} \mathrm{NaCl}$ showed a number of changes compared to control. No plasmolysis and changes in plasma membrane were noticed in response to salinity. The ultrastructure of
Fig. 4 Ultrastructure of radicle meristematic cells of lupine embryo axes grown for $12 \mathrm{~h}$ on Heller medium without $\mathrm{NaCl}$ (control condition). $C W$ cell wall, $G A$ Golgi apparatus, $E R$ endoplasmatic reticulum, $M$ mitochondrium, $N$ nucleus, $O B$ oil body, $P$ plastid, $S$ starch, $V$ vacuole

control cells showed typical morphology (Fig. 4). Nuclei localized in the central part of the cells with domination of electron-sparse chromatin and several region of electrondense chromatin were observed (Fig. 4a, h). Vacuoles were small and distributed evenly. Endoplasmic reticulum was mainly rough, evenly distributed. The Golgi apparatus had five or six closely stacked cisternae asymmetrically differentiated from the cis to trans faces, with small vehicles budding from the trans end (Fig. 4e). Cells of control embryo axes showed ellipse-shaped normal mitochondria with welldeveloped cristae (Fig. 4b, c, g). Starch grains either single and large, or forming aggregates were noticed (Fig. 4a, h). Oil bodies were small, localized adjacent to tonoplast or plasmalemma (Fig. 4a, c). Electron-dense inclusions were visible inside oil bodies. Ultrastructure of meristematic cells of embryo axes roots treated with $250 \mathrm{mM} \mathrm{NaCl}$ for $12 \mathrm{~h}$ (Fig. 5) showed increase in the number of vacuoles, which were distributed evenly or formed aggregates with membranous structures inside (Fig. 5a, f, g). The lumen of ER cisternae was swollen and the fragmentation of RER was observed (Fig. 5e) Whorls of ER surrounded organelles and cytoplasm (Fig. 5b,f). Sometimes an arc of ER formed tightly wound concentric rings (Fig. 5b). In mitochondria reduced amount of electron-dense areas was observed (Fig. 5c, g). Oil bodies looked the same as on medium without salt, but occurred more frequently (Fig. 5a, g). The rate of chromatin condensation increased and more electron-dense heterochromatin regions were formed inside nuclei (Fig. 5a, h). Starch grains were missing. Under $500 \mathrm{mM} \mathrm{NaCl}$ concentration (Fig. 6) deformations in the shape of Golgi apparatus were observed (Fig. 6e). Mitochondria showed orthodox conformation, which is characterized by a reduced number of cristae, narrowed mitochondrial intermembrane space and mitochondrial matrix with low electron density (Fig. 6c, f, g). Vacuoles were more frequent and with some membrane structures inside them (Fig. 6b, f). Rough ER formed whorls surrounding plastids, mitochondria, vacuoles and cytoplasm (Fig. 6b). Changes in the shape and conformation of chromatin were observed showing more regions with electrondense chromatin (Fig. 6a, d, h). Starch grains were missing. Oil bodies showed the same structure as in cells of embryo axes treated with $250 \mathrm{mM} \mathrm{NaCl}$ (Fig. 6a, b).

\section{Discussion}

Abiotic stresses like salinity have a severe impact on plant growth and metabolism and lead to changes at the 

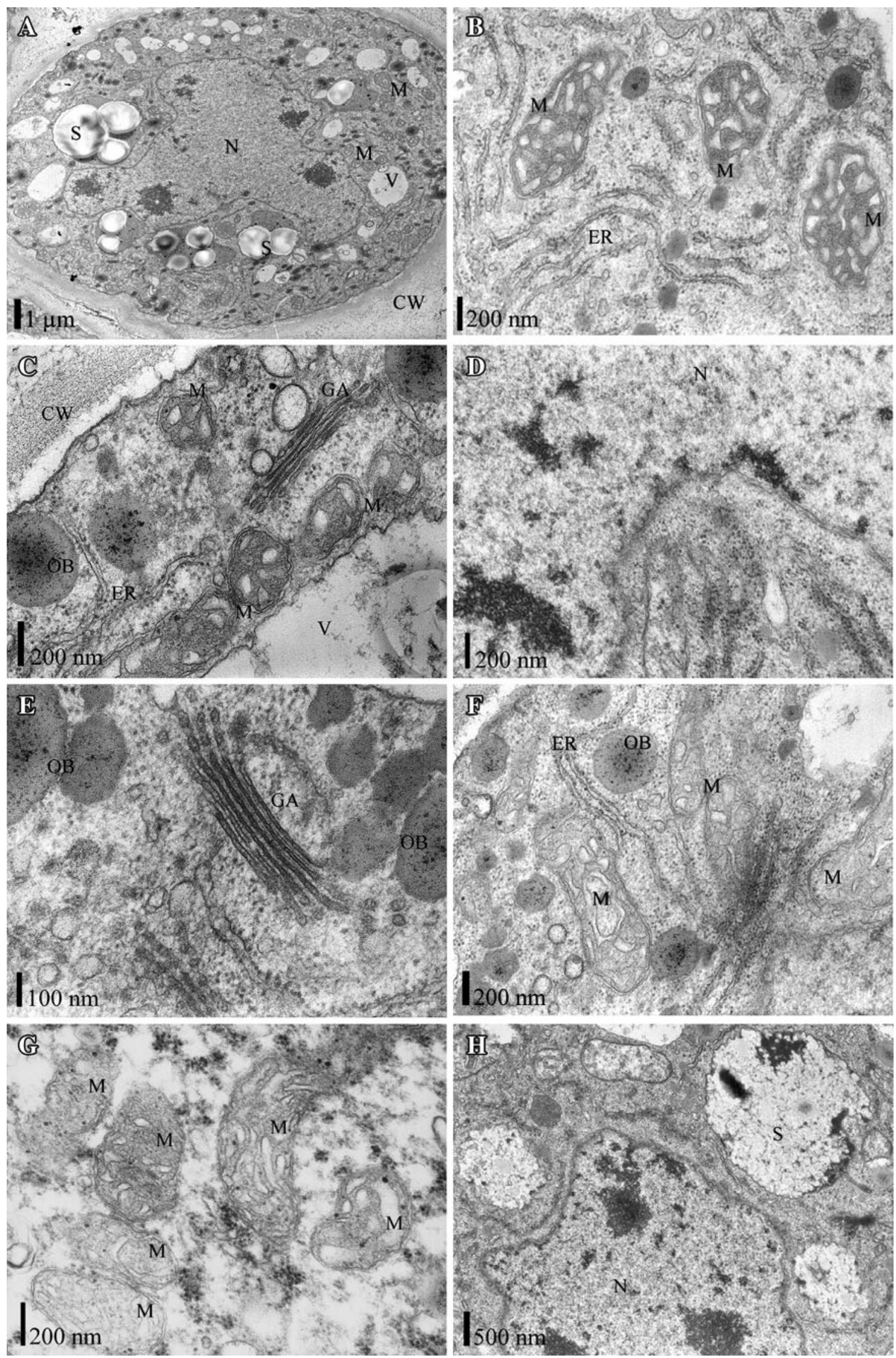
Table 1 Oxygen consumption by embryo axes

\begin{tabular}{llll}
\hline $\mathrm{NaCl}$ concentration in the growing medium & $0 \mathrm{mM}$ & $250 \mathrm{mM}$ & $500 \mathrm{mM}$ \\
\hline Respiration rate $\pm \mathrm{SD}\left(\mathrm{nM} \mathrm{O}_{2} \mathrm{~min}^{-1} \mathrm{~g}\right.$ of fresh weight $\left.^{-1}\right)$ & $81.2 \pm 6.3^{* *}$ & $55.6 \pm 8.1^{* *}$ & $21.3 \pm 2.5^{* *}$ \\
\hline
\end{tabular}

Oxygen consumption of lupine embryo axes grown for $12 \mathrm{~h}$ on Heller medium with $250,500 \mathrm{mM} \mathrm{NaCl}$ and without $\mathrm{NaCl}$

** Results differ statistically with $P<0.05$

physiological and molecular levels (Shulaev et al. 2008). Two principal adverse effects of salinity are osmotic stress and ionic stress. Salinity reduces the ability of plants to take up water by decreasing water potential in the soil and exerts toxic effect of sodium and chloride ions. Both ionic and osmotic components of salinity stress modulate plant response. The very first step of seedlings growth after radicle protrusion is of great importance for plant growth and development, particularly under stress conditions such as salinity (Ashraf and McNeilly 2004). This study focuses on ultrastructural responses of lupine embryo axes under salinity induced cell death. The experimental protocol was designed to establish a salinity-induced PCD model and do not distinguish between osmotic and ionic stress. Despite lots of similarities between osmotic stress and salt stress there are differences in morphological, biochemical, and physiological responses to salt $(\mathrm{KCl}$ or $\mathrm{NaCl})$ and osmotic stress (sorbitol) (Affenzeller et al. 2009). Affenzeller et al. (2009) showed that unicellular green alga Miccrasterias was capable of undergoing programmed cell death under salinity and suggest that, the ionic, rather than the osmotic component of salinity stress triggered PCD in Micrasterias.

DNA cleavage is one of the PCD hallmark as PCDactivated nucleases cleave DNA at linker sites between nucleosomes, resulting in DNA fragmentation (Reape et al. 2008). In this study fragmentation of DNA was detected by total DNA gel electrophoresis (Fig. 2), and by the comet assay of nuclei (Fig. 1). The level of DNA damage measured as parameters of comet of DNA observed in alkaline electrophoresis of nuclei support the toxic effect of salinity on DNA integrity in lupine embryo axes (Fig. 1). The obtained results suggest that the degradation of DNA could be due to execution of PCD in lupine embryo axes in relation to salinity. Degradation of nuclear DNA as a symptom of PCD was observed under saline condition in Thellungiella halophila suspension-cultured cells (Wang et al. 2010), tobacco protoplasts (Lin et al. 2006), Arabidopsis thaliana primary roots (Huh et al. 2002), and in rice roots (Chen et al. 2009). Other results suggesting the occurrence of PCD during salinity stress in lupine embryo axes come from ultrastructure observation using transmission electron microscope. In root meristematic cells of embryonic radicle after $12 \mathrm{~h}$ of 250 and $500 \mathrm{mM}$ salt treatment the rate of chromatin condensation increased (Figs. 5d, h, 6d, h). The condensation of chromatin is one of the symptoms of PCD and was observed in Thellungiella halophila suspension-cultured cells during salt stress induced PCD (Wang et al. 2010). Moreover, loss in cell integrity measured as ability of embryo axes to uptake Evans blue solution increased with a dose of $\mathrm{NaCl}$ in the growing medium (Fig. 3). Such cell injuries may provide execution of reaction leading towards PCD (Rucińska et al. 2004). Further ultrastructure analyses also point towards PCD response in salt stressed lupine embryo axes. These observation revealed increased vacuolization of meristematic cells (Figs. 5a, 6a). Accumulation of vacuoles as well as autophagosomes could be also regarded as one of the PCD features (van Doorn et al. 2011). After $12 \mathrm{~h}$ of treatment with 250 and $500 \mathrm{mM} \mathrm{NaCl}$ the number of vacuoles increased as compared to $\mathrm{NaCl}$ non-treated embryo axes and additionally some autophagic bodies could be distinguished inside vacuoles (Figs. 5f, 6f, g). To confirm autophagic origin of these bodies further biochemical analyses have to be done. Similar structures inside vacuoles were observed in PCD process in the unicellular green alga Micrasterias denticulata during salt stress induced cell death (Affenzeller et al. 2009). Deformations in dictyosomes and Golgi apparatus were observed under $500 \mathrm{mM} \mathrm{NaCl}$ (Fig. 6e), which was also stated during PCD upon $\mathrm{H}_{2} \mathrm{O}_{2}$ (Darehshouri et al. 2008) and salt treatment in Micrasterias (Affenzeller et al. 2009). In saltstressed lupine embryo axis cells, concentric rings and whorls of rough ER were observed (Figs. 5b, f, 6b). The presence of such structures is postulated to be associated with PCD (Hauser et al. 2006), albeit their function remains still poorly understood. These structures were also observed during stress induced PCD (Davies et al. 1987; Kolb et al. 2004; Affenzeller et al. 2009), and in cells with high rates of protein turnover (Gong et al. 1996). Moreover, it was proposed that such reorganization of the ER occurs when the level of respiratory product, probably ATP, is limited or lacking (Morriset 1983; Kolb et al. 2004). In this study oxygen consumption by lupine embryo axes declined in relation to salt concentration (Table 1). Respiration is the primary source of ATP in embryonic axes, thus the decrease in oxygen consumption reduces energy production. ATP deficiency limits ion exclusion and leads to loss of tissue tolerance to stress (Jacoby et al. 2011). Mitochondria in lupine embryonic axes grown on medium without salt were well developed, contained numerous cristae, with an easily distinguishable outer and inner mitochondrial membrane (Fig. 4b, c, f, g). In 

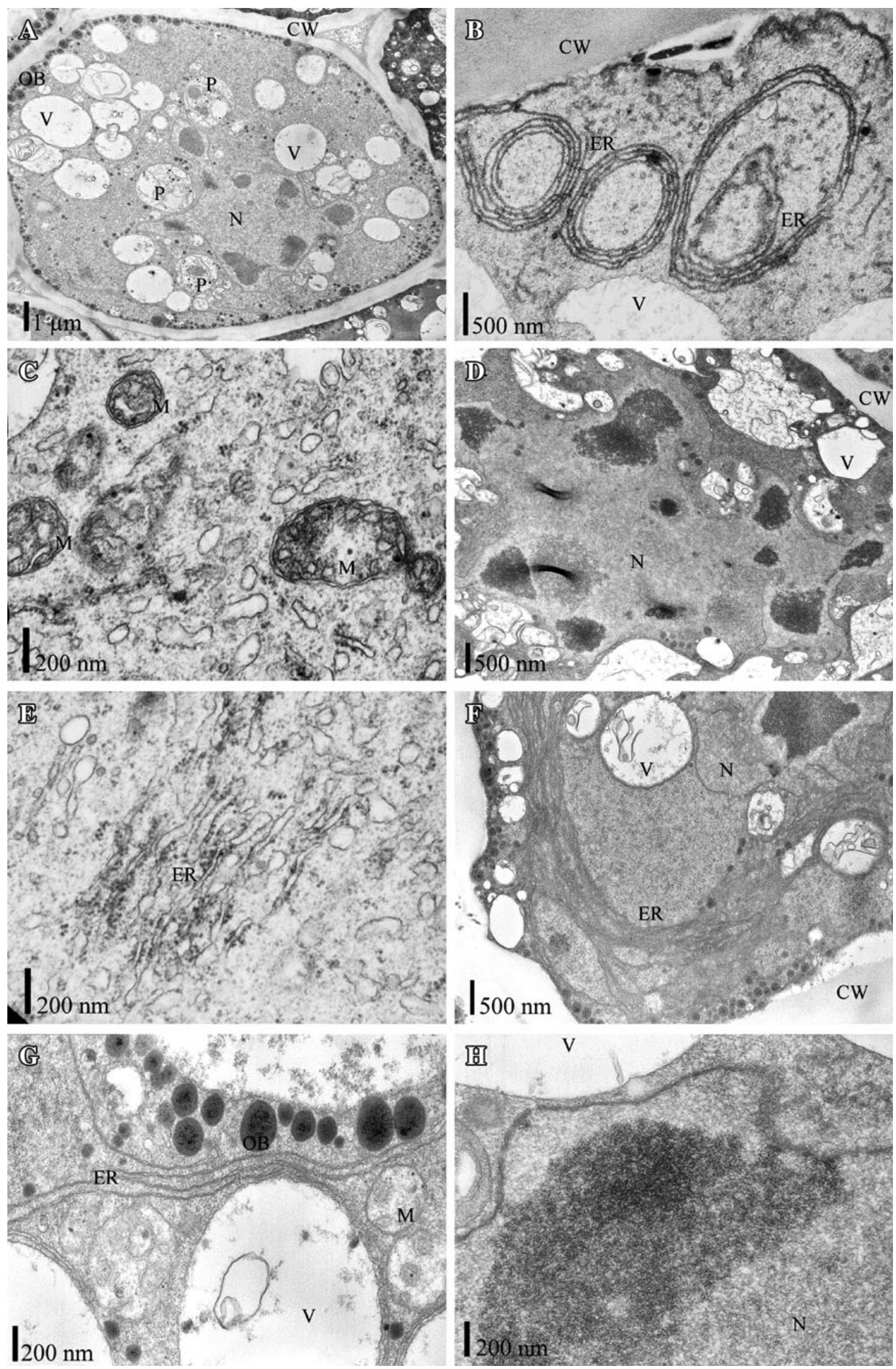

Fig. 5 Ultrastructure of radicle meristematic cells of lupine embryo axes grown for 12 h on Heller medium with $250 \mathrm{mM} \mathrm{NaCl}$. Abbreviations as at Fig. 4 

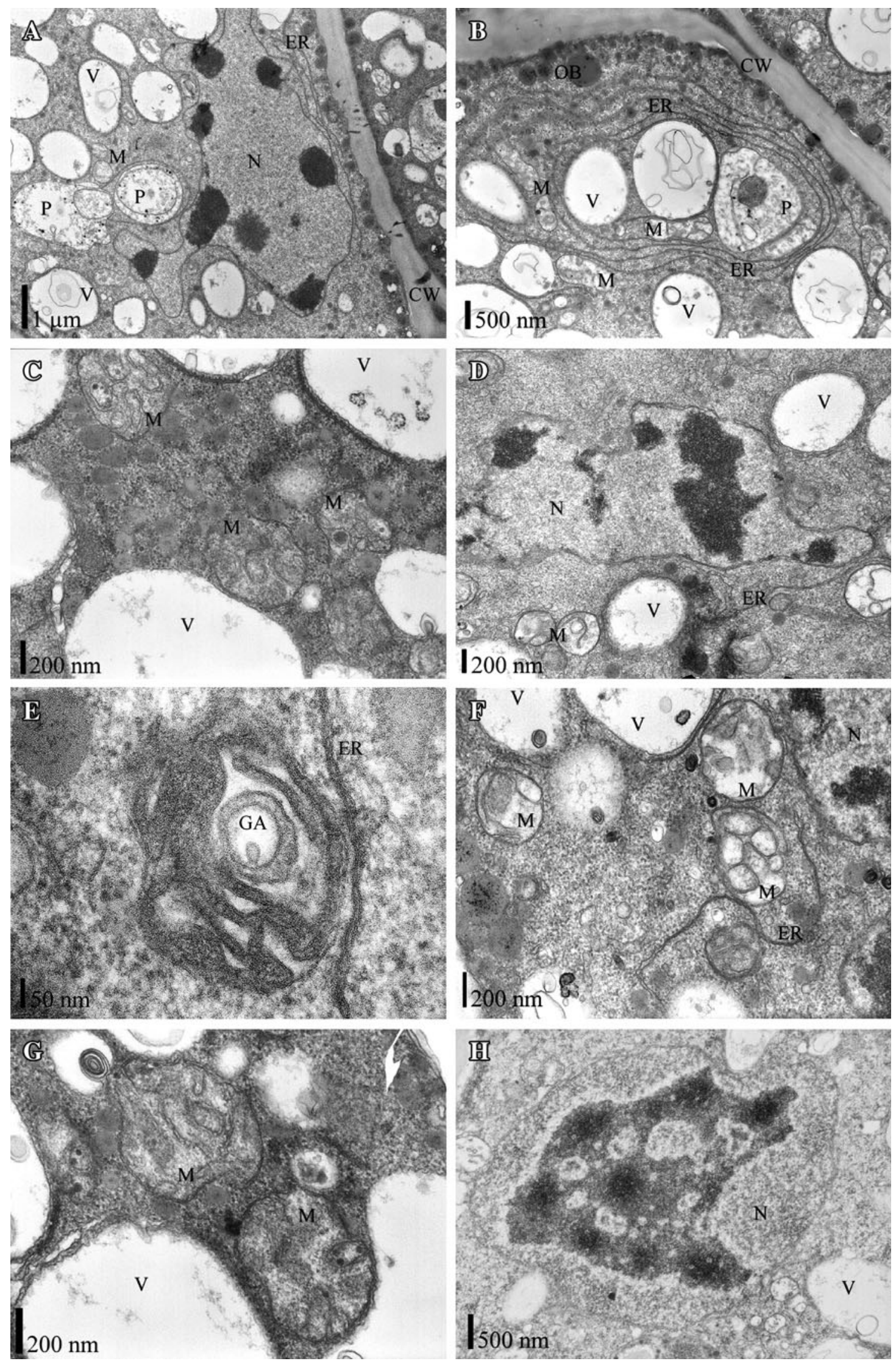

Fig. 6 Ultrastructure of radicle meristematic cells of lupine embryo axes grown for 12 h on Heller medium with $500 \mathrm{mM} \mathrm{NaCl}$. Abbreviations as at Fig. 4 
contrast, the mitochondria from the embryo axes treated with $250 \mathrm{mM} \mathrm{NaCl}$ are characterized by a swollen cristae, narrowed mitochondrial intermembrane space and mitochondrial matrix with low electron density (Fig. 5c, g) which is characteristic of the orthodox conformation. Mitochondria display orthodox conformation when ADP is limited and ATP production is at low level (Hackenbrock 1966). However, changes in mitochondrial architecture may also merely reflect osmotic changes in the local environment (Mannela 2008). Under $500 \mathrm{mM} \mathrm{NaCl}$ treatment the mitochondria exhibited morphological abnormalities with obscure cristae (Fig. 6c, f, g). Disorganization of mitochondria up to disintegration of their cristae was observed. Such abnormalities and deformations of mitochondria under stress induced PCD were also observed in maize roots (Gunawardena et al. 2001), roots of neotropical trees (Kolb et al. 2004) and in unicellular green alga (Darehshouri et al. 2008). Under salinity condition vesicular-shaped inner membrane could be observed in lupine embryo axes (Fig. 6f). Vesicular-shaped cristae were reported in apoptotic mitochondria in animal cells. Youle and Karbowski (2005) hypothesized that such mitochondrial inner membrane shape is a precursor step to organellar fragmentation, a requirement for apoptosis to proceed. Another characteristic features of lupine embryo cells under salinity is lack of starch grains in comparison with control (Figs. 4a, 5a, 6a). According to Borek et al. (2006) starch grains are missing in dry seeds and are normally synthesized and accumulated in lupine embryo axes during imbibition and early phase of germination, so they could be observed in imbibed embryo axes before seed coat rapture. The decline of starch under salinity could be due to their faster degradation or reduction in the rate of synthesis.

\section{Conclusion}

In this study we focused on ultrastructural characterization of lupine embryo axes cells during salinity stress. Ultrastructural observations and analysis of DNA degradation confirm the activation of PCD reaction in lupine embryo axes as a response to high salt concentration. It is hard to judge whether the function of PCD is to protect the plant life by sacrificing some part of cells, or its execution is mainly due to damages accumulation during severe stress. Salinity tolerance/adaptation is essentially a compromise between damage and recovery to stress. Selective PCD in plant roots is thought to be an adaptation to high salt conditions. Future works should focus on comparative transcriptomic and/or proteomics approaches and advanced functional analysis of the differentially expressed proteins for better and comprehensive understanding of plant response to salinity stress.
Author contribution $\quad$ Ł. Wojtyla cultured lupine embryo axes, prepared material for transmission electron microscopy, observed and analysed ultrastructure changes, isolated DNA and performed electrophoresis, studied oxygen consumption and drafted the manuscript. R. RucińskaSobkowiak isolated nuclei, performed alkaline electrophoresis of nuclei and analyzed them statistically. S. Kubala assisted in ultrastructure observation and analysis and measured loss in cell viability. M. Garnczarska designed and coordinated the study and was responsible for verification of the paper.

Acknowledgments We thank Ms. Maria Przybylska for technical assistance and Mr. Michał Róg for help in ultrastructural observation. This work was supported by Polish State Committee for Scientific Research (KBN), Grant N N303 471038. ŁW is grateful to the Greater Poland Province Employment Office and European Social Fund for their financial support for the best PhD students in PO KL 8.2.2. program.

Open Access This article is distributed under the terms of the Creative Commons Attribution License which permits any use, distribution, and reproduction in any medium, provided the original author(s) and the source are credited.

\section{References}

Affenzeller MJ, Darehshouri A, Andosch A, Lütz C, Lütz-Meindl U (2009) Salt stress-induced cell death in the unicellular green alga Micrasterias denticulate. J Exp Bot 60:939-954

Andronis EA, Roubelakis-Angelakis KA (2010) Short-term salinity stress in tobacco plants leads to the onset of animal-like PCD hallmarks in planta in contrast to long-term stress. Planta 231: 437-448

Ashraf M, McNeilly T (2004) Salinity tolerance in Brassica oilseeds. Crit Rev Plant Sci 23:157-174

Baker CJ, Mock NM (1994) An improved method for monitoring cell death in cell suspension and leaf disc assays using evans blue. Plant Cell Tissue Organ Cult 39:7-12

Borek S, Ratajczak W, Ratajczak L (2006) Ultrastructural and enzymatic research on the role of sucrose in mobilization of storage lipids in germinating yellow lupine seeds. Plant Sci 170:441-452

Chen X, Wang Y, Li J, Jiang A, Cheng Y, Zhang W (2009) Mitochondrial proteome during salt stress-induced programmed cell death in rice. Plant Physiol Biochem 47:407-415

Darehshouri A, Affenzeller M, Lütz-Meindl U (2008) Cell death upon $\mathrm{H}_{2} \mathrm{O}_{2}$ induction in the unicellular green alga Micrasterias. Plant Biol 10:732-745

Davies DD, Kenworthy P, Mocquot B, Roberts K (1987) The effects of anoxia on the ultrastructure of pea roots. In: Crawford RMM (ed) Plant life in aquatic and amphibious habitats. Blackwell Press, Oxford, pp 265-277

De Pinto MC, Locato V, de Gara L (2012) Redox regulation in plant programmed cell death. Plant Cell Environ 35:234-244

Doorn WG, Beers EP, Dangl JL, Franklin-Tong VE, Gallois P, HaraNishimura I, Jones AM, Kawai-Yamada M, Lam E, Mundy J, Mur LAJ, Petersen M, Smertenko A, Taliansky M, Van Breusegem F, Wolpert T, Woltering E, Zhivotovsky B, Bozhkov PV (2011) Morphological classification of plant cell deaths. Cell Death Differ 18:1241-1246 
Edwards K, Johnstone C, Thompson C (1991) A simple and rapid method for the preparation of plant genomic DNA for PCR analysis. Nucleic Acids Res 19:1349

Gong F-C, Giddings TH, Meehl JB, Staehelin LA, Galbraith DW (1996) Z-membranes: artificial organelles for overexpressing recombinant integral membrane proteins. Proc Natl Acad Sci USA 93:2219-2223

Gunawardena AHLAN, Pearce DM, Jackson MB, Hawes CR, Evans DE (2001) Characterisation of programmed cell death during aerenchyma formation induced by ethylene or hypoxia in roots of maize (Zea mays L.). Planta 212:205-214

Hackenbrock CR (1966) Ultrastructural bases for metabolically linked mechanical activity in mitochondria. I. Reversibility ultrastructural changes with change in metabolic steady state in isolated liver mitochondria. J Cell Biol 90:269-297

Hauser BA, Sun K, Oppenheimer DG, Sage TL (2006) Changes in mitochondrial membrane potential and accumulation of reactive oxygen species precede ultrastructural changes during ovule abortion. Planta 223:492-499

Heller R (1953) Recherches sur la nutrition minerale des tissus végétaux cultivé in vitro. Ann Sci Nat Botanique et Biologie Végétale 14:1-223

Huh G-H, Damsz B, Matsumoto TK, Reddy MP, Rus AM, Ibeas JI, Narasimhan ML, Bressan RA, Hasegawa PM (2002) Salt causes ion disequilibrium-induced programmed cell death in yeast and plants. Plant J 29:649-659

Jacoby RP, Taylor NL, Millar AH (2011) The role of mitochondrial respiration in salinity tolerance. Trends Plant Sci 16:614-623

Karnowsky MJ (1965) A formaldehyde-glutaraldehyde fixative of high osmolarity for use in electron microscopy. J Cell Biol 27:137-138

Kolb RM, Dolder H, Cortelazzo AL (2004) Effects of anoxia on root ultrastructure of four neotropical trees. Protoplasma 224:99-105

Koshiba T, Kobayashi M, Matoh T (2008) Boron nutrition of tobacco BY-2 cells. V. Oxidative damage is the major cause of cell death induced by boron deprivation. Plant Cell Physiol 50:26-36

Koukalová B, Kovařík A, Fajkus J, Široký J (1997) Chromatin fragmentation associated with apoptotic changes in tobacco cells exposed to cold stress. FEBS Lett 414:289-292

Lin J, Wang Y, Wang G (2006) Salt stress-induced programmed cell death in tobacco protoplasts is mediated by reactive oxygen species and mitochondrial permeability transition pore status. J Plant Physiol 163:731-739

Ma W, Xu W, Xu H, Chen Y, He Z, Ma M (2010) Nitric oxide modulates cadmium influx during cadmium-induced programmed cell death in tobacco BY-2 cells. Planta 232:325-335
Mannela CA (2008) Structural diversity of mitochondria: functional implications. Ann NY Acad Sci 1147:171-179

Miller G, Suzuki N, Ciftci-Yilmaz S, Mittler R (2010) Reactive oxygen species homeostasis and signalling during drought and salinity stresses. Plant Cell Environ 33:453-467

Morriset C (1983) Effects of energetic shortage upon the ultrastructure of some organelles, in excised roots of Lycopersicon esculentum cultivated in vitro. I. Reversible modifications of the endoplasmic reticulum. Cytologia 48:348-362

Pfosser A, Amon A, Lelley T, Heberle-Bors E (1995) Evaluation of sensitivity of flow cytometry in detecting aneuploidy in wheat using disomic and ditelosomic wheat-rye addition lines. Cytometry 21:387-393

Qu GQ, Liu X, Zhang YL, Yao D, Ma QM, Yang MY, Zhu WH, Yu S, Luo YB (2009) Evidence for programmed cell death and activation of specific caspase-like enzymes in the tomato fruit heat stress response. Planta 229:1269-1279

Reape TJ, Molony EM, McCabe PF (2008) Programmed cell death in plants: distinguishing between different modes. J Exp Bot 59:435-444

Rucińska R, Sobkowiak R, Gwóźdź E (2004) Genotoxicity of lead in lupin root cells as evaluated by the comet assay. Cell Mol Biol Lett 9:519-528

Shabala S (2009) Salinity and programmed cell death: unravelling mechanisms for Ion specific signalling. J Exp Bot 60:709-712

Shabala S, Demidchik V, Shabala L, Cuin TA, Smith SJ, Miller AJ, Davies JM, Newman IA (2006) Extracellular $\mathrm{Ca}^{2+}$ ameliorates $\mathrm{NaCl}$-induced $\mathrm{K}^{+}$loss from Arabidopsis root and leaf cells by controlling plasma membrane $\mathrm{K}^{+}$-permeable channels. Plant Physiol 141:1653-1665

Shulaev V, Cortes D, Miller G, Mittler R (2008) Metabolomics for plant stress response. Physiol Plant 132:199-208

Spurr AR (1969) A low viscosity epoxy resin embedding medium for electron microscopy. J Ultrastructural Res. 26:31-43

Wang J, Li X, Liu Y, Zhao X (2010) Salt stress induces programmed cell death in Thellungiella halophila suspension-cultured cells. J Plant Physiol 167:1145-1151

Youle RJ, Karbowski M (2005) Mitochondrial fission in apoptosis. Nat Rev Mol Cell Biol 6:657-663

Zhu J-K (2002) Salt and drought stress signal transduction in plants. Ann Rev Plant Biol 53:247-273 